Шапсугова Мариетта Дамировна

Кандидат юридических наук, доцент Старший научный сотрудник сектора предпринимательского и корпоративного права Институт государства и права РАН

\title{
FAMILY ENTERPRISE: APPROACHES TO FORMALIZATION
}

Аннотация: Актуальные проблемы правового регулирования семейных предприятий возникли на стыке семейного и гражданского, семейного и предпринимательского права. Указанное делает актуальными исследования в данной cфepe.

Формализация статуса семейного предприятия может осуществляться как по пути создания специального правового режима осуществления предпринимательской деятельности, так и по пути формирования правосубъектного образования. В статье исследуются оба метода легализации правоотношений с участием членов семьи.

С использованием исторического подхода рассмотрен опыт регулирования семейных предприятий по закону РСФСР от 25.12.1990 № 445-1 «О предприятиях и предпринимательской деятельности», крестьянских (фермерских) хозяйств, зарубежный опыт. В контексте правового режима семейного предприятия проанализирован законопроект "О внесении изменений в Федеральный закон "О развитии малого и среднего предпринимательства в Российской Федерации" в части закрепления понятия "семейное предприятие".

Ключевые слова: семейное предприятие, крестьянское (фермерское) хозяйство, мальй и средний бизнес, малое и среднее предпринимательство, гражданин как субъект предпринимательского права, семья.

Keywords: family business, peasant (farm) economy, small and medium business, small and medium business, citizen as a subject of business law, family.

The family can be considered as a form of individual human activity [1, p. 3].

The first well-known family dynasties of Russian entrepreneurs began to take shape in a single Moscow state under Tsar Ivan the Terrible. In the 15th century, the formation of the 
Stroganovs, Nikitnikovs, Shorins, Sveteshnikovs, Venevitinovs dynasty began. The beginning of the 18th century saw the emergence of the merchant dynasties of the Morozovs, Ryabushinsky , Prokhorovs, Gorbunovs, Skvortsovs, Demidovs [2, p. 10-22; 3, p. 11-12].

Nowadays, family entrepreneurship is considered as having signs of the initiative, independence, carried out systematically, at their own risk and property responsibility, the activities of family members in any organizational and legal form established by law, carried out in order to make a profit, to meet socio-economic, property needs and family interests. [4, p. 1213]. The importance of family entrepreneurship in solving social problems is expressed in its functions. The family business has a significant impact on the democratization of market relations. Its role is also important in forming the "middle class," which is formed by increasing citizens' entrepreneurial activity. The development of family business correlates with the growth of self-employment, helps reduce social tensions. Within a family enterprise framework, minors are involved in labor activities, and entrepreneurship is popularized among young people, new jobs are created, including for disabled people, pensioners. Thus, family entrepreneurship contributes to progress in social entrepreneurship [5, p. 8].

In the field of family entrepreneurship, there is a tendency to form stable intersectoral ties between family, corporate and entrepreneurial relations, and organizational and labor relationships between family members, the priority among which are family [6; 7, p. 409-424].

A family business can be considered as a form of the family business.

The creation of family businesses was provided for by the Law of the RSFSR of December 25, 1990 N 445-1 "On enterprises and entrepreneurial activity" (after this - the law on enterprises) [8]. According to this law, a family enterprise is an organizational-legal form of individual private enterprise owned by family members in the common property, unless otherwise provided by the contract between them (Part 1 of Art. 8). The enterprise's property was formed from the property and income of the family, or the acquisition by the family of a state or municipal enterprise, the responsibility of the owners of the enterprise was regulated by its charter.

The entrepreneurship of spouses in the Republic of Kazakhstan is arranged according to a similar model. By Part 3 of Art. 32 of the Business Code of the Republic of Kazakhstan, it is a form of joint entrepreneurship carried out based on joint ownership. Family entrepreneurship is also formed based on joint ownership of a peasant farm or common joint ownership of a privatized dwelling. 
In modern Russian law, the legal personality form of a family business is enshrined - a peasant (farm) economy, created by Federal Law of June 11, 2003, N 74-FZ "On a peasant (farm) economy." One of such an economy's signs is its members' relationship and (or property) of a farm. This law, established by this law, belongs to its members based on joint ownership unless otherwise provided by an agreement between them.

The development of family entrepreneurship is one of state policy priorities, harmonizing public and private principles in this area [10, p. 26-41].

Thus, the family trading business development recognized the basic direction of the consumer market [11].

Concept of state family policy in the Russian Federation for the period up to 2025, approved by Decree of the Government of the Russian Federation of August 25, 2014, N 1618-r provides for solving the problem of developing the economic independence of the family and creating conditions for it to independently solve its social function, including the development of entrepreneurship and teaching family members the basics of family entrepreneurship and business.

Given the high social importance of family entrepreneurship, it is not surprising that a family enterprise's concept and features have been developed for a long time by science, primarily economic.

It is proposed that the legality of family ties between members of a family enterprise is traced to the degree of kinship with the head of the family and his spouse [4, p. 16]. We believe this view is narrow since the head of the family is not always the family's head (the beneficiary of the family business). It may not be the oldest member of the family.

It is also proposed to consider the personal labor participation of family members as a sign of a family business. In this case, the criterion indicating such participation may be the average number of persons united by family ties: among the employees of a small and microbusiness entity - at least $50 \%$, and the share in the wages fund - at least $30 \%$, and kinship is determined not by the head of the enterprise, but by the leadership in the family [4, p.16].

Considering the strategic importance of family entrepreneurship for the formation of the middle class, as well as by the instruction of the President of the Russian Federation of July 2, 2019, N Pr-1204 and the order of the Government of the Russian Federation of July 7, 2019, N SA-P13-5683, the Ministry of Economic Development and Trade, a Draft Federal Law "On Amendments to the Federal Law" On the Development of Small and Medium-Sized Businesses in the Russian Federation "in terms of consolidating the concept of" family enterprise " [12]. 
The developers of the draft law see the development of the family business as creating new organizational and legal forms and giving special status to existing enterprises. The very inclusion of norms on family businesses in the Federal Law of July 24, 2007 N 209-FZ "On the development of small and medium-sized businesses in the Russian Federation" [13](after this referred to as the law on the development of small and medium-sized businesses) means their assignment to this category of business entities.

It is assumed that with the adoption of the bill, a legal basis will be created to provide support measures for family businesses.

The draft law proposes to assign the status of a small and medium-sized business entity to a family enterprise ( by analogy with social business entities ), which has the following characteristics:

6. Its members - members of one family own in total more than fifty percent of shares (voting shares) and one of the family members is the sole executive body of such a legal entity, or the chairman of the board of directors (supervisory board) of a business company or at least one of the family members is entrusted the management of business partnership affairs,

7. at least fifty percent of members of a production cooperative, consumer cooperative, peasant (farm) economy are members of the same family,

8. at least fifty percent of an individual entrepreneur who works for him at his main place of work are his family members.

For family members, developers of the bill carried spouses, parents, children, sisters, brothers, grandsons, grandfathers, and grandmothers of each spouse, sisters, and brothers of each spouse, adoptive parents.

Compared to the list of family members in housing and family law, the list is supplemented by the brothers and sisters of the parents of each of the spouses. At the same time, it did not include, for example, stepmother and stepfather, actual educators. Thus, the logic of forming the list of family members in the draft law is not apparent.

The authors of the bill also used a quantitative criterion - a fifty percent line. However, it is not the quantitative indicator of participation that matters, but the ultimate beneficiaries' figures, which are not always participants or shareholders of the company.

The question of the expediency of separating the family business into a special legal organizational form remains open. We believe that the format of the special legal regime proposed by the draft law is preferable. At the same time, for its identification, a deep and thorough justification is needed. 
The sign of kinship, fixed by the law, is not always sufficient for the criterion of nepotism. First of all, a family business is characterized by a typical family interest in it.

Thus, in our opinion, the specific features of a family enterprise are kinship (and the ties of adoptive parents and adopted children equated to it), the presence of common family interest. The common property of the ultimate beneficiaries can be singled out as an optional feature.

List of references:

1. Gladkovskaya E.I. Family interest in property legal relations of spouses: dis ... Candidate of Legal Sciences . 0 Krasnodar, 2007 .-- 202 p.

2. Volkov L.A. Family entrepreneurship in Russia: continuity and specificity of management - Yekaterinburg: Publishing house Ural. un-ta, 2019 .-- 356 p.

3. Shnurovozova T.V. Family business in Russian - M .: Publishing house - trade corporation "Dashkov and K", - 208 p.

4. Barkova L.A. Family Entrepreneurship in the Mechanism of Legal Support for Harmonization of Family Interests: Diss ... Candidate of Legal Sciences . - Tver, 2014 .-- 189 p.

5. T.Yu. Nazarova Family entrepreneurship in the Russian Federation: directions of development: dissertation of the candidate of economic sciences . - Tambov, 2008 - 149p.

6. Levushkin A.N. Family spousal entrepreneurship and the sale of spouses' business under the legislation of the Russian Federation // Laws of Russia: experience, analysis, practice. 2018. N 4. / [Electronic resource] access mode of the ATP "Consultant plus" (date of treatment 10/30/2020).

7. Letova N.V. Trends in the development of property relations between spouses in modern conditions. In the book: Legal fate of business during divorce and inheritance. Moscow, 2020.S. 409-424.

8. Law of the RSFSR dated 25.12.1990 No. 445-1 "On enterprises and entrepreneurial activity" (hereinafter referred to as the law on enterprises) // Vedomosti SND and Armed Forces of the Russian Federation, 27.12.1990, No. 30, art. 418.

9. Federal Law of June 11, 2003 N 74-FZ "On Peasant (Farm) Economy" // Collected Legislation of the Russian Federation of June 16, 2003 N 24 Art. 2249.

10. Zankovsky S.S. Public and private principles in the legal regulation of the economy. In collection: Entrepreneurial law in the XXI century: continuity and development. Academic Law University at the Institute of State and Law of the Russian Academy of Sciences; MZ Press. Moscow, 2002. 
11. Order of the Government of the Russian Federation of 06/02/2016 N 1083-r $<$ On approval of the Strategy for the development of small and medium-sized enterprises in the Russian Federation for the period up to 2030> (together with the "Action Plan (" roadmap ") for the implementation of the Strategy for the development of small and medium-sized enterprises in Of the Russian Federation for the period up to 2030 ") // Collected Legislation of the Russian Federation", 06/13/2016, N 24, Art. 3549.

12. Draft Federal Law "On Amendments to the Federal Law" On the Development of Small and Medium-Sized Businesses in the Russian Federation "in terms of consolidating the concept of" family enterprise ". [Electronic resource] URL : http : // www . Consultant . Ru / cons / cgi / online . cgi ? rnd = 27 A 804 ACB 09 C 3 AA 6200 AD 4 D 9 BC 3 CDD 60 \& base $=$ PRJ \& $\mathrm{n}=191,071 \& \mathrm{dst}=100030 \&$ cacheid $=$ AE 10053521 A 7168 C 2 F 5 BEB 08 CCECF $768 \&$ mode $=$ chgreview \& req $=$ doc \# 043249805651703366 (date of treatment $10 / 12 / 2020)$.

13. Federal Law of July 24, 2007 N 209-FZ "On the development of small and medium-sized businesses in the Russian Federation" // Collected Legislation of the Russian Federation of July 30, 2007 N 31 Art. 4006. 